that poore Ladie should bee intreated, whom hee knew to bee vertuous, and whom himselfe had loued. Masistes refused to put her away; alleaging his owne loue, her deseruing, and their common Children, one of which was married to the Kings Sonne, as reasons important to moue him to keepe her. But in most wicked manner Xerxes reuiled him; saying, That hee now should neither keepe the Wife which hee had, nor haue his Daughter whome hee had promised vnto him. Masistes was much grieued with these wordes, but much more, when returning home, hee found his Wife most butcherly mangled by the Queene Amestris, who had caused her Nose, Lips, Eares, and Tongue to bee cut off, and her Breasts in like manner, which were cast vnto Dogs. Masistes enraged with this vilanie, tooke his way with his children, and some Friends, towards Bactria, of which Prouince hee was Gouernour, intending to rebell and auenge himselfe. But Xerxes vnderstanding his purpose, caused an Armie to bee leauied which cut him off by the way, putting him and all his Companie to the sword. Such was the tyrannicall condition of the Persian Gouernement; and such are generally the effects of Luxurie, when it is ioyned with absolute power.

Yet of Xerxes it is noted, that he was a Prince of much vertue. And therefore Alexander the Great, finding an Image of his ouer-throwne, and lying vpon the ground, said, That hee doubted, whether, in regard of his vertue, hee should againe erect it, or, for the mischiefe done by him to Greece, should let it lie. But surely whatsoeuer his other good qualities were, he was foolish, and was a coward, and consequently mercilesse....

\title{
Ch. VII. Of things that passed in Greece from the end of the Persian Warre to the beginning of the Peloponnesian
}

